

\section{DISCLAIMER}

This report was prepared as an account of work sponsored by an agency of the United States Government. Neither the United States Government nor any agency Thereof, nor any of their employees, makes any warranty, express or implied, or assumes any legal liability or responsibility for the accuracy, completeness, or usefulness of any information, apparatus, product, or process disclosed, or represents that its use would not infringe privately owned rights. Reference herein to any specific commercial product, process, or service by trade name, trademark, manufacturer, or otherwise does not necessarily constitute or imply its endorsement, recommendation, or favoring by the United States Government or any agency thereof. The views and opinions of authors expressed herein do not necessarily state or reflect those of the United States Government or any agency thereof. 


\section{DISCLAIMER}

Portions of this document may be illegible in electronic image products. Images are produced from the best available original document. 


\title{
REPORT ON THE STATE-OF-THE-ART REVIEW FOR LMFBR SOURCE RANGE FISSION COUNTER
}

\author{
L. C. Wimpee
}

\section{Approved:

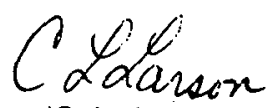 \\ C. L. Larson}

Prog̣ram Mạnạger
Approved:

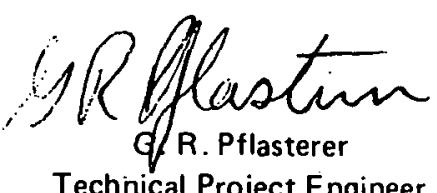

Approved:
Technical Project Engineer

Plant Systems \& Equipment

Prepared for the

U.S. Atomic Energy Commission

Contract AT(04-3)-189

Project Agreement 65

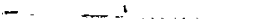

NOTICE

This report was prepared as an account of work sponsored by the United States Government. Neither Che United States nor the United States Atomic Energy Commission, nor any of their cmployes nor any of their contractors, subcontractors, or their nor any of makes any warranty, express or implied, legal liability or responsibility for the ar assumes any pleteness or usefulness of any inform accuracy, com. product or process disclosed information, apparatus, would not infringe privately own represents that its use would not infringe privately owned rights.

$14 p / 150 c$ S\&PSE wjh 2/73

Reprint
BREEDER REACTOR DEPARTMENT • GENEÁÄLL ELECTRIC CUMYAN'Y' SUNNYVALE, CALIFORNIA 94086

\section{GENERAL ELECTRIC}

D. L. Gilliland, Manager Sensor and Penetration Seals Engineering 


\section{NOTICE}

This report was prepared as an account of work sponsored by the United States Government. Neither the United States nor the United States Atomic Energy Commission, nor any of their employees, nor any of their contractors, subcontractors, or their employees, makes any warranty, express or implied, or assumes any legal liability or responsibility for the accuracy, completeness or usefulness of any information, apparatus, product or process disclosed, or represents that its use would not infringe privately owned rights. 


\section{TABLE OF CONTENTS}

1. Introduction . . . . . . . . . . . . . . . . . . . . . . . . . . . 1

1.1 Requirements of the Detector . . . . . . . . . . . . . . . . . . . . . . 1

1.2 Purpose of Review . . . . . . . . . . . . . . . . . . . . . . . . . 1

2. Standard Commercially Available Detectors . . . . . . . . . . . . . . . . . . . 1

2.1 Out-of-Core Detectors . . . . . . . . . . . . . . . . . . . . . . . . . . . . . 1

2.2 In-Core Detectors . . . . . . . . . . . . . . . . . . . . . . . . . . . . . . . . 1

2.3 Detectors in France and U.K. . . . . . . . . . . . . . . . . . . . . . . . . . . . . 2

2.4 Experimental Detectors . . . . . . . . . . . . . . . . . . . . . . . . . . . $\quad$. 2

3. System Approach • . . . . . . . . . . . . . . . . . . . . . . . . . . . 2

4. Cables . . . . . . . . . . . . . . . . . . . . . . . . . . . . . 2

5. Materials . . . . . . . . . . . . . . . . . . . . . . . . . . . . . . 4

6. Detcotor , . . . . , . . . , . . . . . . . . . . . . . . . . . . . . 1

6.1 Ceramic-Metal Seals . . . . . . . . . . . . . . . . . . . . . . . . . . . . . 4

6.2 Detector Geometry . . . . . . . . . . . . . . . . . . . . . . . . . 5

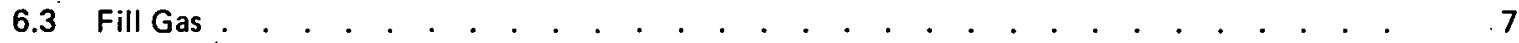

6.4 Uranium Coating . . . . . . . . . . . . . . . . . . . . . . . . . . . . . . . . 7

6.5 Processing . . . . . . . . . . . . . . . . . . . . . . . . . . . . . . 7

7. Summary . . . . . . . . . . . . . . . . . . . . . . . . . . . . . . . . .

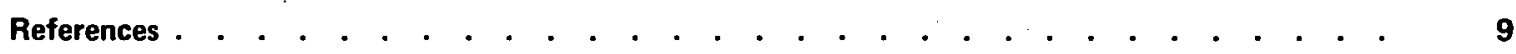

Distribution . . . . . . . . . . . . . . . . . . . . . . . . . . . . . . 11 


\title{
STATE OF THE ART REVIEW FOR LMFBR SOURCE RANGE FISSION COUNTER
}

\author{
L. C. Wimpee
}

\section{INTRODUCTION}

A source range neutron monitoring (SRM) channel for LMFBR requires that low level neutron flux be monitored in the presence of gamma flux levels of approximately $10^{6} \mathrm{R} / \mathrm{hr}$ and at temperatures of $850^{\circ} \mathrm{F}$ to $1050^{\circ} \mathrm{F}$. At present there are no commercially available components suitable for this channel and thus it is necessary to develop detectors, cables and electronics to provide sustained service under the severe conditions imposed by the LMFBR. Investigations of commercially available components ${ }^{1}$ have revealed that existing out-of-vessel detectors are not satisfactory even though external cooling might be provided. In-core SRM detectors used in BWRs and PWRs lack the neutron sensitivity and gamma discrimination capability. They are also marginal at the operating temperature of the LMFBR. Typically, maximum temperature catalog ratings of the in-core detectors are $600^{\circ} \mathrm{F}$ to $750^{\circ} \mathrm{F}$.

\subsection{REQUIREMENTS OF THE DETECTOR}

Because of the superior gamma discrimination capability of fission counters as compared to boron lined proportional counters and $\mathrm{BF}_{3}$ proportional counters, ${ }^{2}$ the fission counter was chosen as the detector for this application. It will he necessary for the detector to perform for 2 to 3 years at temperatures of $850^{\circ} \mathrm{F}$ to $1050^{\circ} \mathrm{F}$.

The detector should be capable of providing 10 counts per second at the channel readout in the presence of $1 \times 10^{6} \mathrm{R} / \mathrm{hr}$ during shutdown of the reactor. ${ }^{3}$

\subsection{PURPOSE OF REVIEW}

As a first step in the development of a source range neutron detector for the LMFBR, a state of the art review was conducted to take advantage of previous work and provide a sound basis for the development. This review describes investigations, development and design activities related to neutron monitoring instruments and associated components applicable to a high temperature fission counter for LMFBR source range neutron monitoring. The sources for the review are published literature, discussions with personnel at the National Laboratories and unpublished reports from the National Laboratories.

\section{STANDARD COMMERCIALLY AVAILABLE DETECTORS}

\subsection{OUT-OF-CORE DETECTORS}

The commercially available detectors evaluated for possible use in FFTF have been found to be inadequate. ${ }^{1}$ In general, these detectors were designed for low temperature and relatively low gamma flux applications. Large electrode spacings, from 0.120 to 0.180 in., which are commonly used, do not provide for the fast collection time necessary for satisfactory gamma discrimination at $10^{6} \mathrm{R} / \mathrm{hr}$. In addition, large electrode spacings require an operating voltage which is high enough that the selection of cables for use with these detectors is critical since the combination of elevated temperature and high voltage required may create conditions at which the cable generates noise. Although these detectors are adequate for low temperature applications they will not provide reliable service above $350^{\circ} \mathrm{F}$. 11 has been reported that the uranium thickness of $2 \mathrm{mg} / \mathrm{cm}^{2}$, which is normally used in these detectors, does not provide the most satisfactory platcau for gamma discrimination ${ }^{4}$ even though the absolute neutron sensitivity may be fairly high.

\subsection{IN-CORE DETECTORS}

The in-core fission counters used in BWRs and PWRs are inadequate for use in the FFTF and LMFBR; the sensitivity is much too low; they are not designed to provide gamma discrimination at $10^{6} \mathrm{R} / \mathrm{hr}$; and, while they could easily survive at the $350^{\circ} \mathrm{F}$ ambient in the cooled wells of the FTR, they have not been qualified for use at the $850^{\circ} \mathrm{F}$ to $1050^{\circ} \mathrm{F}$ ambient in uncooled instrument tubes of the LMFBR. The cables used with these detectors, normally coaxial with stainless steel condiuctors and with alumina, magnesia, or quartz insulation, have unsatisfactory pulse transmission and screening characteristics. 
It appears that while the technology associated with the standard commercially available detectors might be extended and improved upon to provide a satisfactory source range detector for LMFBR and FFTF, presently available detectors are not adequate.

\subsection{DETECTORS IN FRANCE AND U.K.}

Much of the fundamental work in detector design and applicable to LMFBR control has been conducted in France and the U.K. ${ }^{5}, 6,7,8,9,10,11$ The British workers have laid a solid foundation for the design of high temperature fission counters for high gamma use, and very early recognized the need for the approach to gamma discrimination outlined in this report. The French have done some very good work in development of detectors, cable, and seals and have advocated the same approach to gamma discrimination as the British. Both the British and the French have built and tested detectors which approximate that outlined for use in LMFBR; however, the electrode spacings are considered larger than desirable for fast collection time.

\subsection{EXPERIMENTAL DETECTORS}

In the U.S. there have been sporadic attempts at design of fission counters for high temperature application; however, it appears that these detectors were not the result of full scale development programs but rather of limited programs aimed at satisfying specific requests. One evaluation of high temperature fission counters produced by three manufacturers showed that while deficiencies were present, the capability of producing satisfactory high temperature detectors exists. ${ }^{12}$ The problems identified in this evaluation were loss of sensitivity after exposure to elevated temperatures, change in cable characteristics, and a microphonics problem at high temperature.

\section{SYSTEM APPROACH}

The most promising approach to a source range neutron monitoring channel for LMFBR has been described and evaluated by Roux et al., ${ }^{4}$ and Goodings ${ }^{8}$ and further evaluated by Hoitink et al.1 ${ }^{1}$ This system consists of:

1. Fission counter with fast collection time.

2. High temperature cable with good pulse transmission characteristics.

3. Fast rise time, low noise preamplifier with input matched to the characteristic impedance of the cable, operated in the current mode. ${ }^{26}$

4. Fast associated electronics for the remainder of a counting system.

At shutdown, the detector-electronics system should provide $10 \mathrm{cps}$ at the system readout with a signal-to-noise ratio of at least 10 to 1 . The collection time of the detector should be as short as possible consistent with other considerations; 50 to $100 \mathrm{~ns}$ is considered satisfactory and attainable.

\section{CABLES}

Cable operating temperatures in the LMFBR require that they be mineral insulated ${ }^{16}$ and to provide effective screening of interference signals should embody solid outer sheaths. ${ }^{5}, 27$. The cables normally used for in-core detectors are unsuitable even through they satisfy these requirements; typically these cables are coaxial alumina or magnesia insulated with stainless steel inner conductor and sheath. The use of triaxial cable is quite common in France and the U.K. primarily for interference rejection purposes in pulse detectors and wide range d-c detectors, and at times; as a leakage current guard band for power range $d$-c fission chambers. ${ }^{6,14,15,16}$. There is no consensus on the need for triaxial cable even though there is general agreement that it would provide some additional protection against interference. Attachment of triaxial cables to a detector and external connector requires a more complex mechanical arrangement and may be somewhat less reliable because of this requirement. A significant improvement, i.e., reduction, in the transfer impedance of a cable is effected by using a solid copper sheath in place of braided copper or solid stainless steel. At frequencies in the range of 1 to $10 \mathrm{MHz}$ solid copper sheaths may provide a two- to three-decade advantage. ${ }^{27}$ The high resistance of stainless steel conductors attenuates current pulses so that optimum transmission is not possible; therefore, for fast fission counters it is recommended that both cable sheath and conductor, be fabricated of a high conductivity material with OFHC copper being the obvious choice. ${ }^{14,16,27}$ The severe operational environment requires that an outer sheath of stainless steel be provided to protect the copper. A cable developed by 
Sodern in France has, in addition to the stainless steel outer sheath, a stainless steel layer between the copper conductors and the magnesia insulation to prevent migration of copper ions and a resulting loss of insulation resistance at elevated temperatures. ${ }^{16}$ It has been suggested that while this protection against copper migration might be important for $d$-c applications, it is probably not necessary for cables. used with fission counters because the attenuation of current pulses is primarily related to the resistance of the conductors rather than dielectric losses. ${ }^{5}$

Cable noise which has been termed breakdown pulse noise has been reported frequently in the literature.5,6,9,14 It is generated in cables at certain combinations of temperature and applied voltage, normally the threshold being higher for bulk cable than it is for the cable with seal and connector attached. Data taken at Hanford Engineering Development Laboratory (HEDL) indicate that, for candidate cables, the breakdown pulse noise threshold lies above 400 volts $\mathrm{d}-\mathrm{c}$ at the temperatures of interest $\left(850^{\circ} \mathrm{F}\right)$, indicating the desirability of a detector designed for operation at lower voltages. It is generally felt that the pulse breakdown noise stems from a combination of fissures and cracks in the insulator and filling gas-insulator surface breakdown phenomena. This seems to be borne out by the breakdown threshold being lower at the ends of a cable where an interface exists than it is in the middle of a cable. ${ }^{1,14}$ It is generally accepted that higher inșlation denșity is advantạgeous in rạișing the breakdown pulse noise threshold; however, no data were found to support this contention.

Although alumina is commonly used as the insulator for cables used in water cooled reactors, magnesia has higher volume resistivity at all temperatures and has a lower dielectric constant; both are desirable characteristics in cables for pulse transmission. Magnesia insulated cable can. be obtained with copper as well as stainless steel conductors. Silica insulated cable is a somewhat better choice for pulse transmission if a charge sensitive preamplifier is used because of the lower capacitance; however, if current mode signal processing is used, cable capacitance is not important and either alumina or magnesia can be used. Silica insulated cables are not as readily available and are considerably more expensive because of the difficulty in fabricating cable of the density and purity required.

One supplier has successfully fabricated silica insulated coaxial cables with a density of $45 \%$ providing high quality cables of low capacitance (approximately $20 \mathrm{pf} / \mathrm{ft}$ ), high insulation resistance (greater than $10^{14} \mathrm{ohm}-\mathrm{ft}$ ), and the capability of high temperature operation. It is reported that this cable has a relatively high breakdown pulse noise threshold. ${ }^{30}$ Another supplier claims density of $70 \%$ in silica insulated cables and has fabricated samples of silica cable with the Sodern-type sheath. Of the cables tested by HEDL, the French-manufactured Sodern cable, which is magnesia insulated, has the highest threshold for breakdown pulse noise, ${ }^{30}$ however, it has a relatively high capacitance (about $55 \mathrm{pf} / \mathrm{ft})$ and a small center conductor $(0.010 \mathrm{in}$.) which make it somewhat less desirable for pulse transmission and it requires more delicate technique for attachment to the detector.

A comparison of the pulse transmission characteristics of candidate cables was made and it was determined that for this characteristic only, the silica insulated copper conductor cable was superior to magnesia insulated copper conductor cable and that the poorest performance would be an alumina insulated stainless steel conductor cable.

\section{RANKING OF CABLES ACCORDING TO PULSE TRANSMISSION CHARACTERISTICS}

$$
\text { Center Conductor }
$$

1. 0.040 copper

2. ก.ก2n rnpper

3. 0.020 copper

4. $\quad 0.040$ copper

5. 0.100 copper

6. 0.020 copper
Insulation

$0.113 \mathrm{SiO}_{2}$

ก $\mathrm{n} 45 \operatorname{Sin}_{2}$

$0.045 \mathrm{MgO}$

$0.042 \mathrm{SiO}_{2}$

$0.083 \mathrm{SiO}_{2}$

$0.045 \mathrm{Al}_{2} \mathrm{O}_{3}$
Inner Sheath

0.003 copper

n ก15 r.nnner

0.015 copper

0.010 copper

0.003 copper

0.015 copper
Outer Sheath

0.012 SST

ก.015 SST

0.015 SST

0.013 SST

0.012 SST

0.015 SST 
The Sodern cable is not included in this tabulation; the outer layer of stainless steel on the center conductor of the Sodern cable would degrade its pulse transmission characteristics below that of a similar cable which does not have the stainless steel covering. In addition, the small center conductor ( $0.010 \mathrm{in.}$.) would be detrimental:

\section{MATERIALS}

Because of the high ambient temperature surrounding the detector at the retracted position and gamma heating at the startup position, it is necessary to develop a detector to.operate at $1050^{\circ} \mathrm{F}$. Even though it is planned that the source range detector will operate inside a dry instrument tube, the advantages of designing for more general application and for possible immersion in sodium are strong arguments for the use of a 300-series austenitic stainless steel for the detector and cable housing. The radiation resistance, sodium corrosion resistance and:high temperature strength of this material make it the best choice for this application if these were the only considerations. However, the need for nitrogen in the fill gas as discussed below, and the probability of loss of nitrogen by combination with the stainless steel, leads to the probable choice of a nickel base alloy such as Inconel-600 for the detector housing and electrodes since nickel dóes not form a. nitride. The structure would then not be suitable for direct immersion in sodium. The material included within the detector must have low vapor pressure at the operating temperature to preclude deposition of a conductive film on insulating surfaces. Titanium, one of the candidate materials for electrodes was : elminated because titanium deposition on insulators was reported by ANL. In addition, the diffusion of uranium into the titanium is expected to be detrimiental to the neutron pulse height distribution and, titanium would be expected to getter the nitrogen component of the fill gas. Finally, the need for minimizing the relative movement between electrodes and case militates that they be composed of the same material.

Insulators used as structural.members for high temperature application should be high purity alumina, this being the only readily available material with the necessary mechanical and electrical properties. Normally $94 \%$ to $96 \%$ alumina would be used; however, $99.5 \%$ alumina is a better choice since its higher volume resistivity will provide for higher insulation resistance at elevated temperatures.

The temperature gradient between the innermost electrode and the outer housing of the detector requires that expansion or compression members be incorporated into the design of the detector. ${ }^{7}{ }^{10}$ These members, generally in the form of springs, must be made of high temperature spring alloys such as Inconel $x-750$ or Rene 41 . Either of these alloys should be adequate for $1050^{\circ} \mathrm{F}$ operation.

The possibility of fast neutron damage which might result in loss of seal integrity would be a consideration for the LMFBR source range detector if the detector were nonretractable. For insurance against radiation damage high purity alumina, $99.5 \%$ to $99.9 \%$ or possibly sapphire might be selected as the insulator for this seal because of the inverse relation between radiation damage and alumina purity. However, this is not a first order consideration and manufacturing considerations might dictate that a lower purity such as $96 \%$ be used. The possibility of radiation damage also argues against the use of Pyroceram seals which contain a high percentage of glassformers although there is no known data which demonstrate that a Pyroceram seal is unacceptable.

\section{DETECTOR}

\subsection{CERAMIC-METAL SEALS}

It has been generally accepted that there should be a hermetic seal to separate the cable from the detector volume. The seal will prevent movement of gas from the detector to the relatively cooler cable which would reduce the charge collected per fission and cause a loss in effective count rate as temperature increases. In addition it may be advantageous to use different gases in the cable and in the detector to provide a fast gas in the detector and another gas to minimize breakdown pulse noise in the cable. The seal for this application must have good electrical properties, that is, high: insulation resistance and high threshold for breakdown, it should be designed to prevent the deposition of a conductive film across the insulator either from the braze filler metal or other sources, and be mechanically strong to withstand the extremes of temperature and possible mechanical forces: A relatively unknown factor is the reliability of such seals during long term exposure to elevated temperatures. Certain seals appear to fail by development of a leak in the interface indicating a diffusion of filler metal or metallized film into the structural members. 
There is very little information in the literature on seals; however, most manufacturers claim high temperature capabilities for ceramic-metal seals. One high-temperature seal was described which incorporated tapered mating surfaces to provide intimate contact between the ceramic and metal members. It was prestressed by banding the metal members during brazing. This seal design was the best of a number evaluated in the GE Nuclear Materials and Propulsion Operation high temperature fission counter program. ${ }^{19}$ Most commercially available seals are $94 \%$ alumina, molybdenum-manganese metallized, and with nickel-iron or iron-nickel cobalt alloy metal members. The braze filler metal generally is copper, copper-gold, and various silver alloys. Gold transmutes to mercury which in turn has a high vapor pressure, so that gold alloys should be avoided, if possible. The possibility of silver migration across insulating surfaces could prevent its use inside a detector. The most logical choice for braze filler metal for use with ceramics metallized by the sintered metal powder process would be copper..It should be possible to make compression seals, mechanically the strongest type, using the active alloy process. ${ }^{29}$

HEDL evaluated the electrical properties of a coaxial French-made seal which demonstrated that a seal could be fabricated which would not contribute to breakdown pulse noise at the voltages of interest; however, mechanical, thermal, and radiation resistance tests have not yet been performed on this seal. While a number of possibilities exist there are no readily available seals qualified for LMFBR application, and it is apparent that it will be necessary to develop a source for this item.

\subsection{DETECTOR GEOMETRY}

There are a number of approaches to the structural design of fission counters, the most significant of which utilize parallel plates or concentric cylinders. ${ }^{20}$ It is somewhat simpler to develop a mechanically rugged assembly using the concentric cylinder approach with the cylinders supported at both ends. This approach apparently is preferred by the great majority of designers as shown by a review of the literature and the commercially available detectors. ${ }^{19,10,12,8,7,15}$ Based on the premise that reliability goes hand in hand with simplicity, the number of electrodes should be minimized and the electrode support structure should contain as few parts as possible. While internal guard rings are desirable for a high temperature $d-c$ chamber, it is felt that they are not required for a fission counter. In order to shield the signal circuit from external electrical interference it is general practice to provide an outer housing electrically isolated from the outermost electrode except in miniature chambers. ${ }^{15}$ In some designs.the outer housing provides the outer boundary of the detector itself, in others a hermetically, sealed detector element is contained within the outer housing which provides a second containment.

There appear to be three basic approaches to support and electrical isolation of cylindrical electrodes; ceramic posts parallel to the detector axis supporting the ends of electrodes, cantilevered cylinders alternately supported at opposite ends of the detector and relatively massive stepped insulators at each end of the electrodes.

Normally the large out-of-vessel detectors and some of the in-vessel designs incorporate springs to compensate for differential expansion. ${ }^{8}$ These springs are in a variety of forms with helical shapes predominating. Belleville springs are used in some designs and domed tantalum washers have been used as expansion joints in place of springs. ${ }^{10}$

In order to obtain adequate gamma discrimination it is necessary to prevent gamma pulse pile-up and therefore necessary to provide for fast electron collection time.

Since the electrode spacings of most large size fission chambers are about $0.120 \mathrm{in}$. to 0.180 in. the collection time of these detectors is unacceptably long with the gases which are usable for high temperature and high fluence application. Therefore it will be necessary to provide a closer electrode spacing to obtain a fast collection time. Spacings less than $0.060 \mathrm{in}$. should be straightforward, ${ }^{8,7,16}$ a lower limit based on mechanical considerations alone appears as 0.020 in. for a detector with 1000 square centimeters of electrode area. Spacings as low as 0.008 in. are routinely used in BWR-type in-core neutron detectors; however, this would present a difficult mechanical problem in larger detectors and would not be acceptable for a fission counter for reasons discussed below. For a fisssion counter it is nersessary that the fission pulses be sufficiently high to permit discrimination against noise without losing a high percentage of neutron counts; therefore, a limitation to the reduction of electrode spacing is a reduction of pulse height. Since the charge is proportional to the energy deposited in the gap, which for gap dimensions of the order of the range of fission fragments is proportional to the number of gas atoms in the gap, it is, within limits, proportional to the product of pressure and gap. 
where: $\mathrm{q}=$ charge

$$
\begin{array}{lll}
\mathbf{k}_{1} & =\text { constant } \\
\mathbf{p} & =\text { pressure } \\
\mathbf{d} & =\text { electrode spacing }
\end{array}
$$

Therefore, maintaining a constant pressure-gap product provides a constant charge. Even though the pressure is increased in order to maintain a sufficiently high charge per event, the collection time is reduced by a reduction in the electrode spacing as shown by the expression below:

$$
T=k_{2} \frac{d^{2} p}{V}
$$

$$
\begin{array}{rlll}
\text { where: } \cdots: \mathbf{T} & =: & \text { collection time } \\
\because \quad \mathbf{k}_{\mathbf{2}} \cdot & = & \text { constant } \\
\mathbf{d} & = & \text { electrode spacing } \\
\mathbf{p} & = & \text { pressure } \\
\mathbf{V} & = & \text { applied voltage }
\end{array}
$$

This expression is true only for the region in which the drift velocity is linearly proportional to $E / p(=V / d p)$. For a system operated in the current mode, the voltage pulse at the input of the preamplifier may be enhanced by a reduction in electrode spacing even though :the .charge per fission is less. For an ideal current pulse, that is, for zero detector capacitance, the following relation would hold:

$$
\mathrm{V}_{\text {in }}=\frac{\mathrm{q}}{\mathbf{T}} \mathbf{R}
$$

whiere: $\quad V_{\text {in }}=$ peak voltage at input

$$
\begin{aligned}
& q=\text { charge collected } \\
& T=\text { collection time } \\
& \mathbf{R}=\text { input impedance }
\end{aligned}
$$

Combining equations (2) and (3):

$$
V_{i n}=\frac{q R V}{k_{2} d^{2} p}
$$

If the gap were reduced by a factor of two, the charge would be reduced by the same amount; however, the collection time would be reduced by a factor of four resulting in an increase in the voltage into the preamplifier by a factor of two.

$$
\begin{aligned}
& V_{\text {in }}^{\prime}=\frac{q}{2} \frac{R V}{k_{2}\left(\frac{d}{2}\right)^{2} p} \\
& V_{\text {in }}^{\prime}=\frac{2 q R V}{k_{2} d^{2} p}
\end{aligned}
$$

However, since there is a finite detector capacitance and thus a pulse rise time greater than zero, the actual voltage input to the preamplifier would be somewhat less than indicated by (6). A further increase in detector capacitance by decreasing the gap would result in a change in pulse height by some factor less than the inverse of the gap and at some point there would be a net reduction in voltage pulse height because of the increase in detector capacitance. 


\subsection{FILL GAS}

Since source range monitoring for LMFBR requires a fission counter with fast.t collection time it will be necessary that a "fast" gas must be used. A fast gas consists of an inert gas, usually argon, to which is added a small amount of gas such as $\mathrm{CH}_{4} \quad \mathrm{CO}_{2}$ or $\mathrm{N}_{2}$ whose role is to reduce the electron agitation energy such that electron velocity increases. Most common fast gas mixes are not acceptable for use in detectors exposed to high neutron fluence because of radiolysis which results in decomposition of the polyatomic component ${ }^{6,15}$ causing an increase in collection time and thus, effectively, a loss of sensitivity. Argon-nitrogen mixes provide acceptably fast collection time; however, the chemical combination of nitrogen with detector components at elevated temperatures may occur resulting in the loss of nitrogen and, therefore, an increase in collection time. This was reported by the French workers who said that the loss of nitrogen accounted for a change in collection time from 150 nsec to 340 nsec. ${ }^{16}$ This is the only known report of this occurrence and ho data were presented to demonstrate that nitrogen had been lost; however, it does seem reasonable that nitriding of the stainless steel could occur at the test temperature thus removing ritrogen from the fill gas.

Based on drift velocity data it appeared that a mixture of argon and helium would be the best choice of gas since the reported collection time is reasonable ${ }^{23}$ and both components are inert. However, some doubt now appears about the validity of the drift velocity curves and argon-helium mixes may be essentially the same as argon. The question of loss of helium by diffusion has been raised; however, it appears that this would be no problem. Test chambers filled with helium and heated to $600^{\circ} \mathrm{C}$ showed that losses would be negligible. ${ }^{8}$ Since inert gases will not permeate metals ${ }^{21}$ and assuming leak tight welds, the only path for possible helium loss is through the glassy phase of the alumina in the cable seals. F. J. Norton, ${ }^{2}$ a consultant in gas permeation, calculated that the half-life for loss of helium. through a seal would be 3800 years assuming $99.5 \%$ alumina, $2.44 \mathrm{~cm}^{2}$ surface area, $1.9 \mathrm{~mm}$ thickness, 1 atmosphere helium and $1200^{\circ} \mathrm{F}$. The possibility of a change in the rate of diffusion through ceramic as a result of radiation damage has not been answered.

It is probable that the requirements of the detector will dictate that argon-nitrogen be used as a fill gas and as discussed previously the material for electrodes and case will be chosen to preclude the loss of nitrogen through chemical combination.

\subsection{URANIUM COATING}

It has been suggested that thin uranium coatings, approximately $1 \mathrm{mg} / \mathrm{cm}^{2}$, be used in order to obtain a broad relatively flat neutron pulse height plateau and thus minimize the change in effective neutron sensitivity as the discriminator is charged. ${ }^{4}$ Typically, coatings of $2 \mathrm{mg} / \mathrm{cm}^{2}$ are provided in production fission chambers and it is reported that the pulse height plateau is not as well defined as it could be because of the broad spectrum of fission fragment velocities and therefore should be reduced to $1 \mathrm{mg} / \mathrm{cm}^{2}$. Since this would result in a significant loss in absolute sensitivity.it must be carefully considered.

Normally uranium is applied by electroplating uranium oxide onto the electrode surfaces. For most materials the bond between uranium oxide and the substrate leaves room for improvement; however, it is possible to plate onto titanium and then diffuse the uranium into the titanium resulting in a very good bond. A coating applied by sputtering from a $\mathrm{UO}_{2}$ source appears to be a good approach to provide a coating which will be adherent under all operating conditions. $^{24}$ This process would require significantly more effort than electroplating for both development and routine production. It is possible that by improvement of routine electroplating operations through control of the electrode surface finish, preparation of the substrate by thorough cleaning, and in some cases by electroplating an intermediate film such as nickel satisfactory coating will result. It has been reported that the French obtain hard, well bonded coatings from electroplating and that the coatings improve with exposure to high temperature. ${ }^{31}$

\subsection{PROCESSING}

There is a paucity of information in the literature concerning processing of detectors and it is not known whether this results from a lack of interest in such a mundane subject or a widely held belief that there is little to say about it. I $t$ is suspected that both are true to some extent. The vacuum tube industry pays considerable respect to this subject and it is felt that details of cleaning, handling, firing, and assembly outgas can be borrowed from that industry without requiring significant alteration. A typical cleaning routine for parts for vacuum tubes would be degrease, hydrogen fire, 


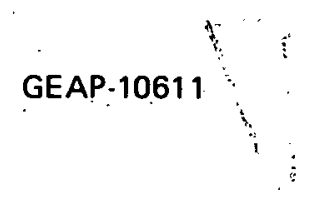

ultrasonic detergent or solvent clean, inert gas dry, vacuum fire, assembly, and, finally, outgas at the highest temperature feasible. The degreasing operation normally involves the use of solvents such as trichlorethylene or methylene - chloride and it is necessary to follow this with an operation which guarantees complete removal of the chlorine residue. The hydrogen firing normally accomplishes three things, it reduces oxides and breaks down organic films on the surface as well as in the interstices of the metal, and replaces gases absorbed by the metal with hydrogen which can be more readily outgassed during the exhaust operation. The ultrasonic cleaning step should be carried out with an industrialtype detergent as the primary cleaning agent. Rinses with deionized water are necessary to remove the detergent solution and will aid in producing a cleaner surface than provided by solvents such as acetone which normally leaves a residue. Since the outgas temperature of a completed detector assembly is generally limited by structural considerations. and the highest vapor pressure material in the assembly, it is desirable to outgas the components separately at the highest temperature feasible and then to outgas the assembly again just prior to backfilling. Although it is not normally done; it may be advantageous to provide an inert gas flush during the early part of the assembly outgas operation so that the mean free path of volatilized materials will be kept as short as possible and thus prevent deposition on other surfaces, primarily insulators. If titanium is used as one of the components it is possible to create a cycle whereby atomic hydrogen evolved from the titanium comes in contact with insulator surfaces where it reduces the metallic oxide creating a water 'molecule which returns to the titanium and is broken down once again freeing atomic hydrogen to start the cycle again. This results in creation of a conductive film on the insulating surface. Thorough vacuum firing of titanium components prior to assembly should prevent this cycle from taking place during the early phases of outgas and an argon flush would provide additional insurance. The backfill gas must be free of contaminants in order to prevent the capture of electrons by electronegative gases and thus reduce the pulse height. An unknown factor is the degree to which contaminants might affect the collection time. 9

\section{SUMMARY}

The: state of the art of design, development and manufacture of high temperature fission counters is somewhat more advanced in. the U.K. and France than in the U.S. It appears that optimization of detector design for high temperature applications has not been considered sufficiently important in the U.S. to justify the effort that would be involved; as a result, there are no commercially available fission counters which will perform adequately in the LMFBR. It will be necessary to carry out a development program aimed at identifying the requirements for a fission counter for LMFBR application, generating a specification and optimizing the parameters of the detector to meet the specification. Certain improvements in the selection of materials, mechanical design, optimization of dimensions and processes along with procurement or development of adequate seals and cables will be necessary to develop a satisfactory detector for the LMFBR:

There are no known obstacles which cannot be overcome but optimization of the nuclear design, development of seals and cables, and development of a uranium coating process are the major items to be attacked. 


\section{REFERENCES}

1. Hoitink, N. C., Jackson, C. N., and Thompson, D. C., Performance Characteristics of Commercially Available Neutron Detection Systems, Hanford Engineering Development Laboratory, January 12, 1972.

2. Typical Residual Neutron Sensitivity as a Function of Gamma Flux, ORNL Drawing 71-11253.

3. Detector Environment and Requirements, ORNL Drawing 71-11251.

4. Roux, D. P., Ricker, C. W., and DeLorenzo, J. T., A Neutron Detection System for Operation in Very High Gamma Fields, (ORNL TM-2693).

5. Level, R. W., Preliminary Study of Characteristics of Mineral Insulated Cable for Reactor Control Pulse Counting Channels, September 1963, (AEEW-M369).

6. Goodings, A., Incore Neutron Flux Detectors for Power Reactors, Nuclear Engineering, July-August 1970.

7. Goodings, A., Some Comments on New Neutron Detection Devices, December 1964, (AEEW-M492).

8. Goodings, A., Developments in High Temperature Neutron Detectors, May 27, 1964, (AEEW-R383). :

9. Goodings, A., A Note on the Irradiation. Testing of a Pulse Flssion Chamber Design, January 1965, (AEEW-M493).

10. Duchene, J., High Temperature Fission Chambers, IRE Transactions on Nuclear Science VNS-9 No. 1, January 1962.

11. Bacconet, E., Conte, R., and Duchene, J., Developments in the Field of Neutron Detectors, CEA Conference 1235, May 21, 1968.

12. Bacastow, J. L., and Swickard, E. O., Test of Six High Temperature Neutron Detectors to 650 ${ }^{\circ} \mathrm{C}$, LA-DC-9611. LASL.

13. Jackson, C. N., and Hoitink, N. C., High Temperature and Gamma Effects on Counting Type Neutron Flux Detectors, IEEE Transactions on Nuclear Science, Vol NS-17, No. 1, February 1970.

14. McMinn, K. W. and Goodings, A., Development of Mineral Insulated Cables for Incore Neutron Detectors, Journal of British Nuclear Society, January 1971.

15. Goodings, A., Radiation Measurerrierits in Nuclear Power, Proceedings of the International Conference, Institute of Physics and Physical Society Conference Series No. 2; Berkeley Nuclear Laboratories, September 1966.

16. Bacconet, E., Conte, R., and Dúchene, J., Performance of Neutron Detectors Developed in France for Reactor Control, CEA Conference 1454, October 1969.

17. Wilson, I., and Orann, A., The Problem Associated with Pu/se Counting Using In-Core Detectors, Conference on Nucleonic Instrumentation, Reading, England, September 23-25, 1968,

18. Goodings, A., Hagger, D., and Phillips, R. D., Reactor Control Neutron Detectors for Operation at High Iémpèratures. Conterence on Nucleonics Instrumentation, Reading, England, September 23-25, 1968.

19. Third Annual Report-High Temperature Materials and Reactor Component Development Programs, Vol. III, Instrumentation and Controls, February 28, 1964.

20. Price, W. J., Nuclear Radiation Detection, McGraw-Hill, 1958. 
21. Norton, F. J., Gas Permeation Through the Vacuum Envelope, 1961 Transactions of Eight Vacuum Symposium and Second International Congress, Pergamon Press, 1962.

22. Norton, F. J:, Private Communication, March 21, 1972.

23. Roux, D. P., Electron Drift Velocities in Various Gases and Gas Mixtures, Collection of open literature data and unpublished data from F. J. Davis and D. P. Roux, ORNL, April 28, 1971.

24. McClanahan, E. D., Moss, R. W., and Busch, R., Application of Sputtering to the Fabrication of Neutron Detection Añodes, (BNWL-5்3).

25. Lafferty, Dushman, Scientific Foundations of Vacuum Technique, Fourth Edition, Wiley, 1966.

26. Fairstein, E., and Hahn, J., “Nuclear Pulse Amplifiers Fundamentals and Désign Practice," Nucleonics, July 1965.

27. Harrison, D., “The Mechanism of Interference Pick-Up in Cables and Electronic Equipment with Special Reference to Nuclear Power Stations," The Radio and Electronic Engineer, March 1965.

28. Hirsch, A., and Cassidy, C. J., Test of Westinghouse Bulk WX31353 Cable, ANL Technical Note, ETD/41905/0013; February 22, 1972.

29. "Kohl, W. H., Materials and Techniques for Electron Tubes, Reinhold Publishing Corp.

30. Hoitink, N. C., Personal communication.

31. Roux, D. P., Personal communication. 


\section{DISTRIBUTION}

Division of Reactor Development and Technology, Headquarters

U.S. Atomic Energy Commission

Washington, D. C. 20545

Attn: Director

Divison of Reactor Development and Technology, Headquarters

U.S. Atomic Energy Commission Washington, D. C. 20545

Attn: Assistant Director. Project Management

Division of Reactor Development and Technology, Headquarters

U. S. Atomic Energy Commission

Washington, D. C. 20545

Attn: Assistant Director, Plant Engineering

Division of Reactor Development and Technology, Headquarters

U.S. Atomic Energy Commission

Washington. D. C. 2n545

Attn: Assistant Director, Reactor Engineering

Division of Reactor Development and Technology, Headquarters

U. S. Atomic Energy .Commission

Washington, D. C. 20545

Attn: Assistant Director, . Reactor Technology

Division of Reactor Development and Technology, Headquarters U.S. Atomic Energy Commission Washingtón, D. C. 20545

Attn: Assistant Director, Program Analysis

Division of Reactor Development and Technology, Headquarters

U. S. Atomic Energy Commission Washington, D. C. 20545

Attn: Chíef, Coolant Chemistry Branch

Division of Reactor Development and Technology, Headquarters

U. S. Atomic Energy Commission Washington, D. C. 20545

Attn: Assistant Director for Engineering Standards

Division of Reactor Development and Technology, Headquarters

U.S. Atomic Energy Commission Washington, D. C. 20545

Attn: Assistant Director for Nuclear Safety
1 Division of Reactor Development and Technology, Headquarters U. S. Atomic Energy Commission Washington, D. C. 20545

Attn: Chief, Core Design Branch

Division of Reactor Development and Technology. Headquarters U.S. Atomic Energy Commission Washington, D. C. 20545

Attn: Chief, Instrumentation and Control Branch

Division of Reactor Development and Technology, Headquarters U. S. Atomic Energy Commission Washington, D. C. 20545

Attn: Chief, Special Technology Branch

Division of Reactor Development and Technology. Headquarters U. S. Atomic Energy Commission Washington, D. C. 20545

Attn: Chief, Fuels and Materials Branch

Division of Reactor Development and Technology, Headquarters. U. S. Atomic Energy Commission Washington, D. C. 20545

Attn: Chief, Reactor Vessels Branch

Division of Reactor Development and Technology, Headquarters U. S. Atomic Energy Commission Washington, D. C. 20545

Attn: Chief, Liquid Metal Projects Branch

Division of Reactor Development and Technology, Headquarters

U. S. Atomic Energy Commission Washington, D. C. 20545

Attn: Chief, Liquid Metal Systems Branch

Division of Reactor Development and Technology, Headquarters U.S. Atomic Energy Commission Washington, D. C. 20545

Attn: LMFBR Program Manager

Division of Reactor Development and Technólogy, Headquarters U.S. Atomic Energy Commission Washington, D: C. 20545

Attn: Chief, Components Branch 
Division of Reactor Licensing U.:S. Atomic Energy Commission Washington, D. C. 20545

Attn: Assistant Director Reactor Technology

Division of Reactor Standards U.S. Atomic Energy Commission Washington, D. C. 20545

Attn: Director

U. S. Atomic Energy Commission Washington, D. C. 20545

Attn: Librarian

RDT Site Office

U.S. Atomic Energy Commission Argonne National Laboratory

P. O. Box 2108

Idaho Falls, Idaho 83401

RDT Site Office

U.S. Atómic Energy Commission Argonne National Laboratory Building 2

Argonne; llinois 60439

\section{RDT Site Office}

U.S. Atomic Energy Commission Atomics International

P. O.Box 1446

Canoga Park, California 91304

RDT Site Office

U. S.:Atomic Energy Commission General Electric Company

310 DeGuigne Drive

Sunnyvale, California 94086.

RDT Site Office

U. S. Atomic Energy Commission:

Oak Ridge National Laboratory

P. O. Box X

Oak Ridge. Tennessee 37830

RDT Site Office

U. S. Atomic Energy Commission Westinghouse Electric Corporation P. O. Box 154

Madison, Pennsylvania 15663

RDT Site Office

U. S. Atomic Energy Commission Gulf General Atomic, Inc.

P. O. Box 2325

San Diego, California 92112

President

Hanford Engineering Development

Laboratory

P. O. Box 1970

Richland, Washington 99352
$2: \quad$ Manager

FFTF Project

Hanford Engineering Development

Laboratory

P. O. Box 1970

2

Richland, Washington 99352

Director

LMFBR Program Office

Argonne National Laboratory

9700 South Cass Avenue

2 Argonne, Illinois 60439

Associate Director

Engineering Research \& Development

Argonne National Laboratory

9700 South Cass Avenue

Argonne, Illinois 60439

Associate Director

1

Reactor and Engineering

Sciences

Oak Ridge National Laboratory

P. O. Box X

Oak Ridge, Tennessee $\mathbf{3 7 8 3 0}$

Director

$1 \quad$ Liquid Metal Engineering Center

Atomics International

P. O. Box 1449

Canoga, Park, California 91304

Manager

Idaho Nuclear Corporation

P. O. Box 1845

Idaho Falls, Idaho 83401

Office of the President

1

Atomics International

A Division of North American

Rockwell Corporation

P. O. Box 309

Canoga Park, California 91304

Manager

Advanced Reactor Division

Westinghouse Electric Corporation

P. O. Box 158

Madison, Pennsylvania 15663

1

General Manager

Breeder Reactor Developmient

Operation

General Electric Company

Sunnyvale, California 94086

Contracting Officer

U. S. Atomic Energy Commission

2111 Bancroft Way

Berkeley, California 94704 


\section{BREEDER REACTOR DEPARTMENT}

SUNNYVALE, CALIFORNIA 94086

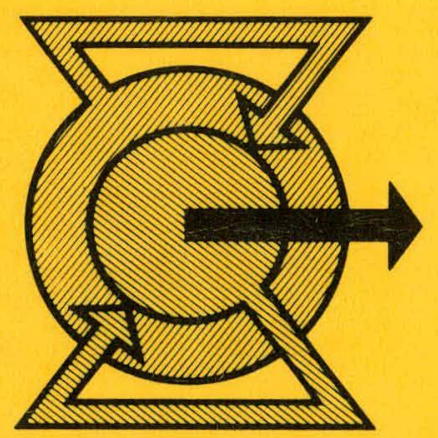

Expanding the World's Energy Reserves

\section{GENERAL ELECTRIC}

